\title{
Brown adipose tissue biology and therapeutic potential
}

\section{Patrick Seale*}

Cell and Developmental Biology, Perelman School of Medicine, University of Pennsylvania, PA, USA

${ }^{*}$ Correspondence: sealep@mail.med.upenn.edu

Edited by:

Ralf Jockers, University of Paris, France

Reviewed by:

Ralf Jockers, University of Paris, France

\section{BROWN ADIPOSE TISSUE}

Brown adipose tissue (BAT) (Figure 1) has been recognized as a key thermogenic tissue in rodents for several decades. However, in the last few years, there has been a resurgent interest in the biology and therapeutic potential of BAT. This has been largely driven by a new understanding that most, if not all, healthy adult humans have significant deposits of BAT which can be activated by cold. Moreover, recent insights into the developmental origins of brown adipose cells and the identification of molecules that regulate brown adipocyte activity have provided a conceptual framework for the design of brown fat-based therapies.

Brown fat cells, when activated, are able to take up and oxidize large amounts of fat and carbohydrate for the purpose of producing heat - a process called adaptive thermogenesis. This transformation of chemical energy into heat at the expense of ATP production is mediated by the presence of Uncoupling Protein1 (Ucp1) in the inner mitochondrial membrane. Ucp1 catalyzes the leak of protons from the intermembrane space back into the matrix, thus reducing the gradient (and its potential energy) used for ATP production.

BAT presumably evolved to protect animals against hypothermia in response to cold exposure. However, BAT is also known to powerfully counteract obesity and metabolic disease, at least in rodents. Numerous studies over recent years revealed that mice with increased amounts of active brown fat are lean, healthy, and able to resist the harmful metabolic effects of high fat diets. Intriguingly, imaging studies in humans show that brown fat activity is reduced in obesity and aging. The field must now address whether the variation in brown fat activity is a cause or consequence of weight gain. Brown fat cells are localized in discrete depots of BAT and are also found clustered amongst white fat cells in white depots. The prevalence and function of these so-called "beige" or "brite" (brown-in-white) cells in humans remains unknown.

There is a growing consensus in the field that brown fattargeted therapies hold tremendous promise for the treatment of obesity and associated health consequences. It is also increasingly clear that brown fat can function as an effective sink for disposing of excess glucose and fatty acids. This suggests that brown fat-based therapies could be very effective for treating insulin

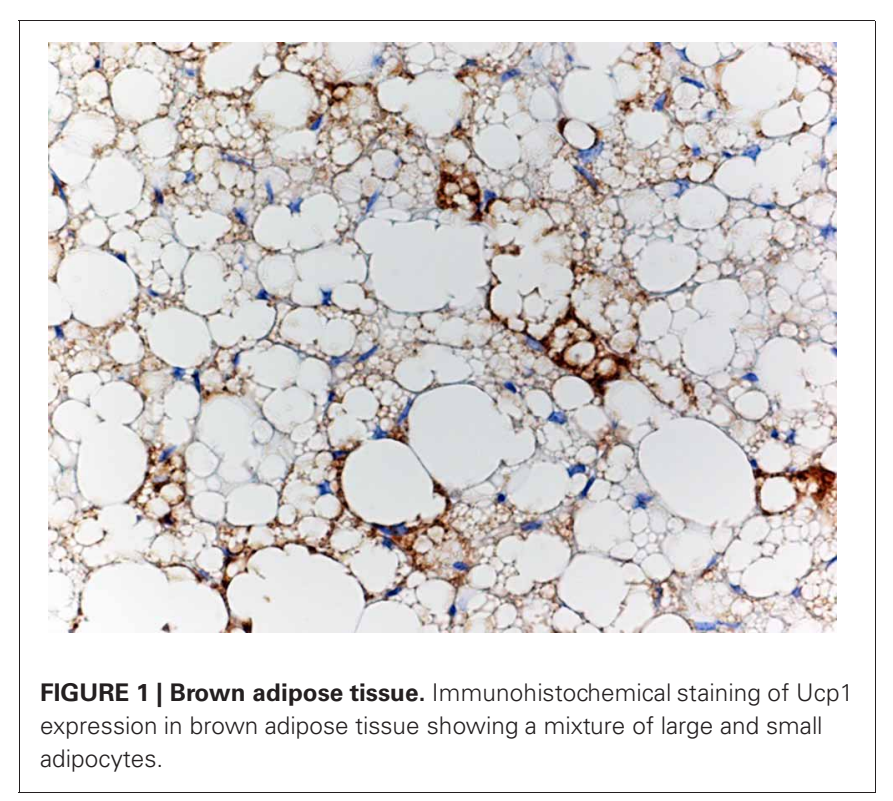

resistance, type-2 diabetes, and dyslipidemia without necessarily reducing body weight.

In this Research Topic, we were able to assemble articles from many of the prominent scientists in the field which focused on many different and important aspects of brown fat biology. The topic begins with a historical perspective (Ricquier, 2012) and also includes reviews and original reports on: test systems to study Ucp1 (Hirschberg et al., 2012); the development of brown adipose cells (Boss and Farmer, 2012; Festuccia et al., 2012; Kozak, 2012; Pisani et al., 2012; Scime, 2012; Yadav and Rane, 2012); the influence of genetics (Kozak, 2012); adrenergic and central control of brown adipocyte activity (Collins, 2012; Morrison et al., 2012); human brown adipose cells and imaging methods (Betz and Enerback, 2012; Hu and Gilsanz, 2012; Muzik et al., 2012; Richard et al., 2012; van Marken Lichtenbelt, 2012); and perspectives for brown adipose-based therapeutics (Betz and Enerback, 2012; Boss and Farmer, 2012). I would like to thank all the contributors and reviewers for their help in putting this interesting and timely collection of articles together. 


\section{REFERENCES}

Betz, M. J., and Enerback, S. (2012). Therapeutic prospects of metabolically active brown adipose tissue in humans. Front. Endocrinol. 2:86. doi: 10.3389/fendo.2011.00086

Boss, O., and Farmer, S. R. (2012). Recruitment of brown adipose tissue as a therapy for obesity-associated diseases. Front. Endocrinol. 3:14. doi: 10.3389/fendo.2012.00014

Collins, S. (2012). beta-adrenoceptor signaling networks in adipocytes for recruiting stored fat and energy expenditure. Front. Endocrinol. 2:102. doi: 10.3389/fendo.2011.00102

Festuccia, W. T., Blanchard, P. G., and Deshaies, Y. (2012). Control of brown adipose tissue glucose and lipid metabolism by PPAR $\gamma$. Front. Endocrinol. 2:84. doi: $10.3389 /$ fendo.2011.00084

Hirschberg, V., Fromme, T., and Klingenspor, M. (2012). Test systems to study the structure and function of uncoupling protein 1: a critical overview. Front. Endocrinol. 2:63. doi: 10.3389/fendo.2011.00063

Hu, H. H., and Gilsanz, V. (2012). Developments in the imaging of brown adipose tissue and its associations with muscle, puberty, and health in children. Front. Endocrinol. 2:33. doi: 10.3389/fendo.2011.00033

Kozak, L. P. (2012). The genetics of brown adipocyte induction in white fat depots. Front. Endocrinol. 2:64. doi: 10.3389/fendo.2011.00064

Morrison, S. F., Madden, C. J., and Tupone, D. (2012). Central control of brown adipose tissue thermogenesis. Front. Endocrinol. 3:5. doi 10.3389/fendo.2012.00005

Muzik, O., Mangner, T. J., and Granneman, J. G. (2012). Assessment of oxidative metabolism in brown fat using PET imaging. Front. Endocrinol. 3:15. doi: 10.3389/fendo.2012.00015

Pisani, D. F., Djedaini, M., Beranger, G. E., Elabd, C., Scheideler,
M., Ailhaud, G., et al. (2012) Differentiation of human adiposederived stem cells into "Brite" (Brown-in-White) adipocytes. Front. Endocrinol. 2:87. doi: 10.3389/fendo.2011.00087

Richard, D., Monge-Roffarello, B., Chechi, K., Labbe, S. M., and Turcotte, E. E. (2012). Control and physiological determinants of sympathetically mediated brown adipose tissue thermogenesis. Front. Endocrinol. 3:36. doi: 10.3389/fendo.2012.00036

Ricquier, D. (2012). Uncoupling protein 1 of brown adipocytes, the only uncoupler: a historical perspective. Front. Endocrinol. 2:85. doi: 10.3389/fendo.2011.00085

Scime, A. (2012). The heat is on: a new avenue to study brown fat formation in humans. Front. Endocrinol. 2:118. doi: $10.3389 /$ fendo. 2011.00118

van Marken Lichtenbelt, W. (2012). Human brown fat and obesity: methodological aspects.
Front. Endocrinol. 2:52. doi: 10.3389/fendo.2011.00052

Yadav, H., and Rane, S. G. (2012). TGFbeta/Smad3 signaling regulates brown adipocyte induction in white adipose tissue. Front. Endocrinol. 3:35. doi: 10.3389/fendo.2012.00035

Received: 25 January 2013; accepted: 31 January 2013; published online: 19 March 2013.

Citation: Seale P (2013) Brown adipose tissue biology and therapeutic potential. Front. Endocrinol. 4:14. doi: 10.3389/ fendo.2013.00014

This article was submitted to Frontiers in Cellular Endocrinology, a specialty of Frontiers in Endocrinology.

Copyright (c) 2013 Seale. This is an open-access article distributed under the terms of the Creative Commons Attribution License, which permits use, distribution and reproduction in other forums, provided the original authors and source are credited and subject to any copyright notices concerning any thirdparty graphics etc. 